\title{
The Developmental State in an Era of Finance-Dominated Accumulation
}

\section{Bob Jessop}

Submitted version of chapter in Yin-Wah CHU, ed., ed., The Asian Developmental State: Reexaminations and New Departures, New York: Palgrave-Macmillan, 978-1137-47612-8, pp. 27-55

There have been three main accounts of East Asian export-oriented economic growth in the 1980s: getting prices right, the developmental state, and Confucian capitalism. None is satisfactory and, together, they reproduce the market-state-civil society triplet, which originates in European Enlightenment thinking, and one-sidedly highlight the roots of the miracle in one or other of these ensembles. This suggests the need for an alternative approach to interpreting and explaining economic development and social formations that can provide a more powerful and comprehensive account not only of the East Asian economic miracles but also of their crisis-tendencies and partial recovery from that crisis. This approach should also be able to explain the variety of developmental states in this region and the similarities to, and differences from, cases in other regions. This is one aim of this chapter.

The so-called Asian crisis in the late-1990s prompted a search for alternative economic and political strategies and other ways to recalibrate the developmental state strategy. While this search was home-grown, it was influenced by two strategies that were pursued in advanced economies to exit the crisis of Atlantic Fordism in the 1980s and 1990s. The two main exit routes were the knowledgebased economy (KBE) and neoliberal financialization. Japan had anticipated the $\mathrm{KBE}$ project in promoting the information economy and/or society and it was also embraced relatively early in other East Asian newly industrializing economies (hereafter EANICS). In contrast, financialization seems to have reached East Asia as much through stealth and external pressure as through imitation and overt domestic strategic goal-setting. Yet some East Asian economies, notably Singapore, have also pursued financialization alongside the more dominant knowledge-based growth strategies. So it makes sense to revisit the history and dynamic of the developmental state and its crisis-tendencies, and examine how it has been adapted following 
economic crises. The chapter ends with some remarks on the research agenda that follows from this approach. Considering these themes are the other goals of this chapter.

\section{The Other Canon}

I define the developmental state in three steps. First, the modern state is a local, regional, national, or supranational state that exercises authority over a stable population resident in its territory. Second, in turn, a developmental state (DS) is one that plans, orchestrates or steers economic, political and societal strategies oriented to catch-up with a more advanced reference economy or economic growth dynamic. This definition does not limit the DS to EANICs nor to national territorial states more generally but allows for developmental state strategies over a much longer time span, on different scales, with due regard to the forms of polity, politics, and policies appropriate to the shifting horizon of what it means to catch-up. And, third, for the sake of clarity, I define an apparently rival concept: the competition state. This term was also introduced in the 1980s to describe an allegedly new phenomenon (Cerny 1990; Hirsch 1995). However, like the DS, it can also be given a generic meaning. Here it denotes states that proactively seek economic growth within their borders and/or seek to secure competitive advantages for capitals based within them, even where they operate and may even be headquartered abroad, by promoting the economic and extra-economic conditions that are currently deemed vital for success in competition with economic actors, sectors and spaces in other states. This includes attempts either alone or with other forces (including other states) to project power beyond their political frontiers to shape cross-border or external economic spaces relevant to capital accumulation and social reproduction. This makes the DS, which is oriented to catching up with more advanced economies, a subtype of the competition state. Moreover, although the competition state's strategies and, a fortiori, those of developmental states, may be targeted on specific places, spaces, and scales and directed against specific competitors, they are always and necessarily mediated through the operation of the world market as a whole especially as efforts are made to widen and deepen the latter through strategies of neoliberal globalization. 
The basic idea behind the modern developmental state (DS) dates back to the early $19^{\text {th }}$ century and, in particular, to the work of Friedrich List (1789-1846) on state policies to promote 'catch-up' competitiveness. Through his travels and translations of his work, he contributed to the contemporary co-evolution of German and American theoretical and policy paradigms in political economy. His ideas were also adopted in Russia and Japan. The Listian approach concerned not only political economy, influenced by mercantilist and cameralist ideas, but also questions of national security.

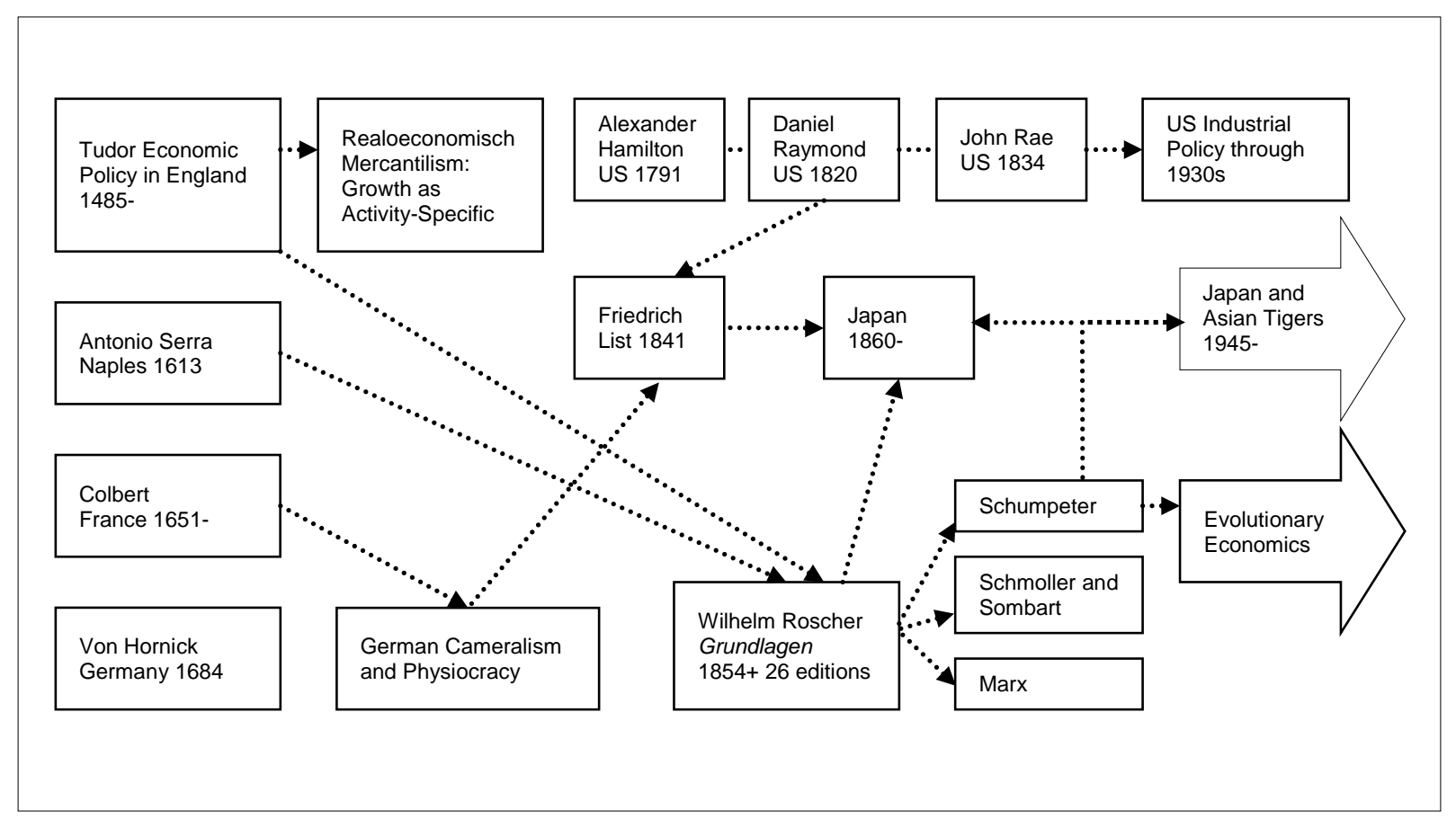

Figure 1. The Knowledge- and Production-Based Canon of Economic Thought

Source: elaborated from Reinert (2004) and Reinert and Daastøl (2004)

List's ideas were already common in Continental Europe and can be traced back at least to the commercial city republics of the Italian Renaissance, the Tudor Plan in England (oriented to catching up with Burgundy, which had grown rich by transforming imported English raw materials into finished goods), the United Provinces (later to become the Netherlands), France (in the form of Colbertism), and various regimes in the German-speaking world. Mercantilism, cameralism, and enlightened despot-ism ${ }^{1}$ were core features of economic-cum-political governance in this 500-year period but became increasingly marginalized with the rise of vulgar 
political economy, neo-classical economics, and free trade doctrines. In contrast, the now marginalized 'other canon' stressed the complementarity of economic and political development and the key role of the state in technological, economic and social development (Freeman 2002, 2004; Reinert and Daastøl 2004; Chang 2005; Caldentev 2008). For examples of the other canon in different times and places, see Figure 1 above.

Later examples of DS occurred in many German-speaking states from the mid1800s through German unification to the 1914-18 World War and in the USA at state and federal level through the $19^{\text {th }}$ century (on the German cases, see Tribe 1995; on the USA, see, for example, Hamilton 1791). ${ }^{2}$ Japan moved towards a DS (modelled on Prussia) in the late $19^{\text {th }}$ century but its capacities were only fully deployed post1945 (Reinert 1995; Johnson 1982). We can also add Kemalist Turkey after 1933 (when the first 5-year plan was introduced) to the list of developmental states that existed before the term was coined (Bayar 1996). Summarizing their economic doctrines and strategies (under the rubric of developmentalism), Erik Reinert suggests that their primary goal is 'to diversify the economy out of a dependency on agricultural and other raw materials alone' (if need be, by exploiting the agricultural sector) and to increase national wealth 'by building a diversified industrial structure where economic activities with large potentials for technological upgrading, subject to increasing returns (falling unit costs), and important synergies (linkages) between a large variety of economic activities play an important role' (Reinert 2010: 3).

Nineteenth-century variants of the 'other canon' rejected the increasingly orthodox view that free trade facilitates modernization. They focused instead on how emerging, developing, peripheral or dependent economies could enhance their position in a world economy and inter-state system imprinted (and thereby transformed) by the rise to dominance of the leading economies. Thus successive latecomers had to find their own path to development and consider the changing world-historical conjunctures and institutional contexts in which catch-up competitiveness strategies are pursued. The 'other canon's' marginalization in mainstream economics is one reason why the DS seems unusual, even shocking, to outside observers in the post-war period. 
List was a prominent critic of the Ricardian doctrine that prescribed global free trade based on the current distribution of factors of production and their productivity. This implies that competitiveness requires efficiency in allocating resources to minimize production costs with a given technical division of labour. List argued that catch-up competitiveness strategies should rely on mercantilist rather than Ricardian free trade, protect infant industries against premature competition, and build a strong cameralist state able to dismantle internal barriers to mobility, trade, and communication (e.g., outdated skills, inadequate infrastructure, and tariff barriers). Thus, his approach anticipated Nicholas Kaldor's theory of growth based on increasing returns to scale. For Kaldor, a post-Keynesian economist, resources should be allocated among available processes and products in terms of their likely impact on growth. He formulated three laws bearing on catch-up competitiveness: first, the rate of growth of productivity in industry depends on dynamic increasing returns to scale in this sector; second, as output and employment in manufacturing increase, workers move from the agricultural sector, leading to an overall rise in productivity; and, third, there is an export demand multiplier because increasing demand leads to increased investment, produces a younger stock of capital, boosts productivity in export industries, and leads to virtuous cumulative causation (Kaldor 1971; cf. Reinert 2004). ${ }^{3}$ Cameralists recommended similar policies, advocating industrial import substitution, export-led growth, and state- and nation-building (Perrotta 1993; Schmoller 1897/1976; Tribe 2008). List opposed free trade because, he argued, it benefits the most advanced economies and blocks the development of semi-peripheral and peripheral economies. Yet he added that, if an economy has caught up, it would also benefit from free trade.

First presented in exile in Outlines of American Political Economy (1827), List, inspired by the mercantilist economic growth already achieved in the USA, elaborated his ideas into a general theory in The National System of Political Economy (1837/1841). This analysed economic development as a series of stages of agricultural, manufacturing and commercial activity. Balanced development of the world economy would require equilibrium among national economies in the temperate zone and their abstention from exploiting lands in the hot zone, which would make them dependent on the manufacturing powers. A recurring theme was his emphasis on technology and production and, especially, the importance of specific national 
endowments and institutional arrangements. Thus his work differed from the prevailing liberal paradigm with its emphasis on commerce, trade and purely quantitative analysis.

In the language of the Amsterdam School of transnational historical materialism, the developmentalist approach corresponds to a productivist rather than liberal (or money) 'proto-concept of control'. Proto-concepts reflect the 'spontaneous' or selfevident interests of a particular fraction of capital and how to secure these interests in the economic, political, and social fields. The productivist variant prioritizes the production of use-values and reflects the interests of industrial capital, which typically needs to valorize a given set of specific assets in a particular space and time; in contrast, the liberal variant prioritizes the mobility of money as money and as capital and is oriented to maximizing exchange-value (or monetary profit). Drawing on these ideal types, Amsterdam scholars explore historically specific, 'comprehensive concepts of control' that aim to unify the ruling class and attract mass support by combining mutually compatible blueprints for balancing the rival interests of different capital fractions and for managing capital-labour relations (van der Pijl 1984: 31). However, because capital-capital and capital-labour relations are marked by social contradictions, it is hard to win and reproduce the class compromises necessary to secure the hegemony of these comprehensive concepts and implement the corresponding strategies (Overbeek 1990; van der Pijl 1998: 4-8). The crisis of one concept, such as the DS project, opens space for struggles over what might replace it and whether this would reflect a productivist or liberal proto-concept of control. This can be seen in the EANICS following the 'Asian Crisis' and again in the wake of the global financial crisis.

The DS concept was first applied explicitly to Japan (Johnson 1982, 1999). It was then adopted for late-industrializing East Asian economies, and has since been applied to other continents (e.g., Latin America, Europe, Africa) and to scales of economic and political organization that are local, regional, or even supranational (e.g., the European Union). Indeed, the myths of the Japanese state proved popular in Western Europe and North America during the early years of Fordist crisis as a progressive reformist paradigm to challenge bankrupt economic strategies (see, further, Caldentev 2008). 
The relevance of this model was already being questioned in the 1990s, however, following the crisis of Atlantic Fordism, the collapse of state socialism in the Soviet Bloc, the end of the Cold War, the turn from Maoism to Dengism in China, the rise of neoliberalism and the Washington Consensus, the training of DS economists and officials in neo-classical economics, and the search for other paths to development. These trends undermined the legitimacy of the DS model and prompted demands to downsize the state and make its functions more market-confirming and conforming.

\section{Revisiting the Concept of the Developmental State}

There are many criticisms of the developmental state paradigm. My critique, for example, noted its embrace of its reified distinction between the market economy and sovereign territorial state (Jessop 2005). Advocates of the DS approach failed to see that the division between market and state is socially constructed and may be maintained, redefined or otherwise manipulated as social forces seek to encourage or prevent the co-deployment of economic and political resources and capacities in pursuit of specific economic, political and security objectives. More sophisticated accounts attributed DS success to operationally autonomous state managers (who may nonetheless have important institutional, organizational, and ideational links to forces beyond the state) who orchestrated a changing balance of markets, networks, government resources and national solidarity to pursue national goals. Depending on the scale of the state, these goals could concern substantive local, regional, national and, indeed, quasi-continental economic interests - corresponding respectively to city-states (Singapore), regional DS (the Third Italy), national DS (Japan, South Korea), and the European Union (e.g., EU President Jacques Delors' growth strategy from 1983 or the EU's Lisbon strategy for 2000-10).

A second problem is the state-centric tendency to focus on properties of the state apparatus (such as Weberian bureaucracy) and/or state managers (such as technocratic expertise) without regard to the specific economic, political and social conditions and particular balance of social forces that enabled an autonomous but embedded state to promote developmental policies or to guide interdependent actors to the same end (Evans 1995; Weiss 1998). This approach highlights that DS do not 
just rely on imperative coordination to promote development but more or less judicially combine several modes of governance to pursue catch-up competitiveness. This emerges more clearly if we see the state as 'government + governance in the shadow of hierarchy'. The variability of governance in this regard was recognized by Séan Ó Riain $(2000,2004)$ when he distinguished the developmental bureaucratic state (DBS) with strong Weberian bureaucracies and strong links to big business, exemplified by Japan and South Korea; from the developmental network state (DNS), where states coordinate cross-border and transnational networks among regions, clusters, and production chains to attract technology and Foreign Direct Investment (FDI) and boost development, exemplified by Taiwan, Israel and Ireland (2004: 4-5). Such distinctions indicate the risk of focusing on state managers at the expense of the broader coalition of forces, within and beyond the state (and its borders), that steer development strategies and enable the state to project its power through these alliances.

A third problem is that the DS theoretical paradigm seeks to explain an apparently anomalous 'economic miracle' in terms of the particular features of an equally anomalous state apparatus. This leads DS theorists to treat phenomenal features, which were possible in special contexts, as the essence of its East Asian variant. This implies that, in contrast to the EANICs' state-centred path to development, Western economies followed a market-centred path of growth. But, as the other canon reveals, the state has played key roles in the West too. Indeed, the later a country embarks on capitalist development, the stronger is the need for state intervention to secure success (cf. Gerschenkron 1962). More generally, rapid economic growth outside East Asia displays substantively equivalent modes of regulation. Thus first- and second-generation DS theoretical and policy paradigms overlooked the actual roles of Western states in capitalist development (including periods of relative laissez-faire, which is a distinctive form of state intervention, as well as the more obviously interventionist periods of mercantilism, imperialism, and the Keynesian Welfare National State) and the conditions that shape state capacities in different contexts.

To overcome these problems, we must rethink the relation between the economic and the political without reifying them or assuming that they are in a zero-sum 
relation; analyse the specificities of accumulation regimes and their modes of regulation rather than study growth rates and other quantitative trends; adopt a relational analysis of the state and state power; and explore the contradictions, dilemmas, and crisis-tendencies of the 'miracle' as well as the continuing strengths of the post-crisis period. This is one way to avoid the risk of equally one-sided analyses of the pre- and post-crisis periods - exaggerating the success of the former and failures of the latter or else interpreting the past as pathological and positing a new start if only the 'right' policy choices are made. It would also enable research on earlier periods where the 'other canon' (developmentalism) prevailed and informed more or less successful catch-up competitiveness strategies based, as Reinert puts it, on the following principles:

1) National wealth cannot be created or based on raw material production in the absence of a manufacturing/increasing returns sector.

2) An inefficient manufacturing/increasing returns sector provides a much higher standard of living than no manufacturing sector (Reinert 2004).

Note two points here. First, the idea of 'competitiveness' is discursively constructed and rests on specific economic imaginaries. This opens space for discursive struggles, with material interests also at stake, over the nature and bases of competitiveness. In addition to Ricardian and Kaldorian accounts, concerned with static comparative and dynamic allocative advantage respectively, we can also mention Schumpeterian competitiveness oriented to entrepreneurship and innovation (Schumpeter 1934; Porter 1990; Jessop 2002; see also below). Different discourses imply different forms of political action with different effects on the competitive positioning of firms, sectors, regions, and nations as well as on the balance of political forces within and beyond the state. Second, as the leading edge of economic development and forms of competition change, so do patterns of competitive advantage and, therewith, the requirements of catch-up competitiveness.

Competition does not occur on a level playing field but around three hierarchies: (1) the relative importance of commercial, industrial, intellectual, and financial markets in setting the overall parameters of competition; (2) the relative super- and subordination of different forms of competition such that, for example, sectors where 
perfect competition survives are subordinate to monopoly or state monopoly competition; and (3) the form of the corporations that set the parameters of competition in each market, with the peak of the global corporate hierarchy occupied at least from the 1980s by denationalized transnational banks and 'stateless' multinational firms (cf. Grou 1985). Thus state capacities to promote competitiveness depend on adapting competitive strategies to the position of national economic space and its key economic actors within the changing competitive hierarchies of the world market. At the same time, however, the capacity to compete is grounded in diverse sources of competitiveness, both economic (broadly considered) and extraeconomic. This raises the question whether increasing return to scale activities, as defined by Kaldor, Reinert and others, may expand from industry to include services and, in particular, whether financialization can provide the basis for DS strategies especially when we include Schumpeterian competitiveness.

\section{The Listian Workfare National State}

To address these issues more concretely, I distinguish four aspects of state involvement in securing capitalist expansion. The first is the broad field of economic policy oriented to securing conditions for profitable private business that cannot be secured through market forces alone. These conditions involve institutional competitiveness (Jessop 2002; Campbell and Pedersen 2007) and include conditions favourable to the 'creative destruction' produced through innovation (Schumpeter 1934). The second aspect is social policy, that is, the state's roles in reproducing labour power individually and collectively over different time horizons from day-to-day through individual lifecycles to intergenerational reproduction. This poses economic problems over the individual and collective suitability of labourpower to capital's needs and its own survival without a secure income or other assets; social problems such as social inclusion and cohesion; and political problems regarding the legitimacy of state intervention in this area and its relation to other identities that workers may have. The third aspect concerns the main scale, if any, on which economic and social policies are decided - even if underpinned or implemented on other scales. This matters because economic and social policies are politically mediated and the scales of political organization may not match those of economic and social life. The fourth aspect is the relative weight of different 
governance mechanisms deployed in efforts to maintain profitability and reproduce labour-power by compensating for market failures and inadequacies. Top-down state intervention is just one mechanism in this regard; and states as well as markets can fail. This suggests the need for other flanking mechanisms and, insofar as these also fail, for attention to the relative balance.

Although the Listian Workfare National State (LWNS) shares certain general properties with other types of capitalist state, it is also distinctive on each dimension. First, it was Listian insofar as it aimed to secure economic growth through export-led industrialization from an otherwise relatively closed national economy and did so mainly by combining catch-up supply-side interventions and neo-mercantilist demand management. Invoking List's name is not a Eurocentric conceit but reflects the influence of his mercantilist approach in Japan and other East Asian economies (cf. Cumings 1999; Weiss 1998). Thus catch-up competitiveness was based on switching investment into sectors and clusters that offered increasing returns to scale in an increasingly integrated national market protected by neo-mercantilist policies and measures but organized to encourage export-led growth rather than importsubstitution alone. This reflects the importance of industrial merchandise trade as the key economic driver in each EANIC's take-off and consolidation phases. Even though Hong Kong was more Ricardian in orientation, its self-described laissez-faire colonial government used critical economic levers, especially its control over land supply and the industrial and domestic property markets, to guide economic growth (Sum 1994).

Second, LWNS social policy had a distinctive workfare orientation. This is reflected in five policies: (1) limiting wage costs qua cost of production, (2) investing in human capital; (3) promoting personal savings and accumulation of assets to assist the reproduction of labour-power over the life cycle; (4) encouraging limited forms of occupational welfare for core workers at factory-level as a means of reducing overall pressure on wage demands; and (5) promoting forms of collective consumption favourable to the exportist growth dynamic, which, as noted by Kaldor and Reinert, involved a virtuous circle of export expansion and reinvestment of export earnings in the next generation of capital goods. Workfare may also involve repression of organized labour not only to contain labour costs in early stages of factor- and 
investment-led growth; but also to limit political opposition in a national security state. $^{4}$

Third, the LWNS was national insofar as economic and social policies were pursued within the historically specific (and socially constructed) matrix of a national economy, national state, and imagined national community. National security discourse, institutions, and practices affected all three elements of this matrix. Neomercantilism was an important basis of economic security; the national state was a national security state; and a strong nationalist ideology was developed to counteract challenges from divided societies (Korea, Taiwan, Singapore, and Hong Kong) or Cold War enemies (Japan). Local governments in Taiwan and South Korea acted mainly as relays for national policies; and the international regimes that were established after WW2, the Chinese revolution, and the Korean War were mainly intended to restore national economies and states within the orbit of the Western bloc under US hegemony.

Fourth, the LWNS was statist insofar as a strong national security state and its institutions (on different levels) were the chief means to guide and supplement market forces in securing economic growth and social cohesion. National security discourse legitimated this role, including the repression of organized opposition and dissent; and it also justified state guidance of market forces even before 'market failure' occurred. Given the residual nature of government social policy and the limited institutional separation of the economic and political, a major secondary role fell to the extended family, guanxi, and other institutions of 'civil society' in the shadow of the state.

To elaborate the LWNS concept, I now consider five sets of social relations that were crucial for EANIC pursuit of catch-up competitiveness. These are the individual and social wage relation; the enterprise form and modalities of competition; the money and credit system (banking and credit systems, the allocation of capital to production, national currencies and world monies, and monetary regimes); the forms of state intervention and its social bases in institutionalized compromise; and the international regimes that link national economies and states into the world system (see Boyer and Saillard 2001; Jessop and Sum 2006). The relative weight of these 
forms varies across modes of growth - as does the relative importance of their twin aspects (e.g., wage as cost of production versus source of demand) in specific conjunctures. The relative dominance of different forms and the relative importance of one or another aspect of each form provide a useful heuristic for exploring the specificity of comprehensive concepts of control, economic strategies, state projects, and hegemonic visions and their respective crisis-tendencies and dynamics (cf. Jessop 2015). I now illustrate these remarks for the LWNS and will do so later for the KBE and financialization.

First, export-oriented growth prioritized the wage as an international cost of production rather than source of domestic demand. This was reinforced where the wage relation was subordinated to an exportist and workfarist (rather than welfare) logic under the auspices of a strong national security state that also repressed or limited workers' struggles for economic, political, and social rights. Nonetheless, as incomes tracked export earnings (if not always in line with productivity), there was growing pressure as well as increasing scope to expand domestic demand for better housing and more consumer durables. This began among the middle classes, spread to organized labour, and supported the growth of capital oriented to domestic mass consumption. This trend is evident in first generation NICs (South Korea, Taiwan, Hong Kong, and Singapore), second generation (Thailand, the Philippines, Malaysia, Indonesia), and most recently, in mainland China, which has been called 'a neo-Listian developmental state with Chinese characteristics' (Breslin 2011: 1336; see also Boyer 2013).

Second, enterprise competition was balanced by cooperation. Sometimes the state and/or peak organizations promoted extensive 'pre-market' collaboration; sometimes firms divided markets to reduce wasteful competition to promote 'catch-up' growth. Small and medium enterprises were also integrated into larger supply chains managed by domestic conglomerates or overseas buyers (and, in Singapore, statesponsored multinationals engaged in inward FDI). Such cooperation-competition was crucial to export-led growth based on flexible imitation, technological, process, and product innovation, and, eventually, targeted movement up the world technological and product hierarchy. At stake here, then, was state guidance or steering rather than top-down planning to develop or transfer new core technologies as motive and 
carrier forces of economic growth and to widen their application to promote competitiveness. In this sense, even the developmental bureaucratic state (Ó Riain 2000) worked through networks. In addition, there were also strong elements of Max Weber's three kinds of political capitalism in developmental states: profits from force and domination, profits from financing political undertakings (e.g., financing political parties, lobbying activities), and profits from unusual deals with political authority (Weber 2009). This would later provide the basis for charges of crony capitalism.

Third, the catch-up strategy privileged credit allocation for long-term growth and prioritized the allocation of national money (and international aid or loans) to investment rather than consumption. This required a strong DS and/or close coordination between banking and industrial capitals (keiretsu, chaebol, KMT-capital and state capital, Singaporean state-owned banks and holding companies) mobilized behind the national economic strategy. Any liberalization of the supply and demand for international credit would have threatened this key pillar of the LWNS - especially in EANICs without strong prudential banking controls - as would expansion of major conglomerates abroad through the building of a regional division of labour and/or their transfer of R\&D and FDI to Europe and North America. Nonetheless, as we shall see below, following the 'Asian crisis', developmental states began to see financial capital not just as an adjunct to industrial and commercial capital but also as a growth engine in its own right, leading to new state strategies to promote financialization.

Fourth, critical in the DS's transformative capacities was the economic and political logic of 'national security' and its reflection in 'exceptional forms' of state (military dictatorship, formalized or de facto one-party rule, etc.) justified by external and internal security threats. Hong Kong differed because of its continued post-war colonial domination and more Benthamite approach to governance and security. In all cases, however, state insulation from popular control would eventually be undermined as perceived security threats declined and economic growth continued, which raised popular expectations about mass consumption and democratic participation. Finally, regarding international regimes, the EANICs had a privileged position in the Cold War and the massive inflow of military aid and other subsidies 
from the USA as part of its Cold War economic, political, military, and ideological strategy.

\begin{tabular}{|l|l|l|l|l|}
\hline \multicolumn{5}{|c|}{ Table 1: Catch-Up Competitiveness } \\
\hline $\begin{array}{l}\text { Basic } \\
\text { Form }\end{array}$ & $\begin{array}{l}\text { Primary } \\
\text { Aspect }\end{array}$ & $\begin{array}{l}\text { Secondary } \\
\text { Aspect }\end{array}$ & $\begin{array}{l}\text { Institutional } \\
\text { fixes }\end{array}$ & $\begin{array}{l}\text { Spatio- } \\
\text { temporal fixes }\end{array}$ \\
\hline State & $\begin{array}{l}\text { Strong state that } \\
\text { guides investment- } \\
\text { led growth }\end{array}$ & $\begin{array}{l}\text { Legitimation through } \\
\text { national security and } \\
\text { continuous growth }\end{array}$ & $\begin{array}{l}\text { Authoritarian } \\
\text { Listian Workfare } \\
\text { National State }\end{array}$ & $\begin{array}{l}\text { Nation- and state- } \\
\text { building and/or } \\
\text { national security }\end{array}$ \\
\hline Capital & $\begin{array}{l}\text { Productive capital } \\
\text { in given (national) } \\
\text { time-place }\end{array}$ & $\begin{array}{l}\text { Mobility of capital } \\
\text { within monopoly } \\
\text { complexes }\end{array}$ & $\begin{array}{l}\text { State-monopoly } \\
\text { complexes and } \\
\text { revolving doors }\end{array}$ & $\begin{array}{l}\text { National economy- } \\
\text { national state- } \\
\text { economic security }\end{array}$ \\
\hline $\begin{array}{l}\text { Com- } \\
\text { petition }\end{array}$ & $\begin{array}{l}\text { Catch-up to bench- } \\
\text { marked sectors } \\
\text { and economies }\end{array}$ & $\begin{array}{l}\text { 'Race to bottom' }+ \\
\text { effects of creative } \\
\text { destruction }\end{array}$ & $\begin{array}{l}\text { Pre-market } \\
\text { collaboration, then } \\
\text { competition }\end{array}$ & $\begin{array}{l}\text { Create and protect } \\
\text { national market as } \\
\text { basis for exports }\end{array}$ \\
\hline $\begin{array}{l}\text { (Social) } \\
\text { wage }\end{array}$ & $\begin{array}{l}\text { Cost of } \\
\text { international } \\
\text { production }\end{array}$ & $\begin{array}{l}\text { Source of national } \\
\text { demand }\end{array}$ & $\begin{array}{l}\text { Occupational and } \\
\text { family (asset- } \\
\text { based) welfare }\end{array}$ & $\begin{array}{l}\text { National reskilling } \\
\text { lus global war for } \\
\text { talents }\end{array}$ \\
\hline
\end{tabular}

\begin{tabular}{|l|l|l|l|l|}
\hline K & Dominant structural forms & & Secondary structural forms \\
\cline { 2 - 4 } $\mathbf{E}$ & & Primary aspect of principal form & & Primary aspect of secondary form \\
\cline { 2 - 4 } & & Secondary aspect of principal form & & Secondary aspect of secondary form \\
\hline
\end{tabular}

Source: original compilation

Table 1 summarizes some of the key features of LWNS-led catch-up competitiveness in these terms during the period when it was relatively successful. This table could also be re-specified for earlier examples of the developmental state, taking account of stages in the development of the world market, different state capacities, and different leading edge technologies and accumulation regimes. In the next section I will examine how the LWNS and catch-up competitiveness were undermined by changes in the leading-edge of competitiveness and shifts in the dynamic of the world market and changes (for further comments on the theoretical assumptions, see Jessop 2015). 


\section{Crisis-Tendencies of the LWNS}

I now turn from comparative statics to a more dynamic account of how regimes handle contradictions and dilemmas by (1) treating some as more important than others; (2) prioritizing one aspect of a contradiction rather than another; (3) switching priority as the secondary aspect becomes more urgent or crisis-prone; and (4) allocating the handling of different contradictions and their different aspects to different scales, networks, or sites of action (cf. Jessop 2015). Following Robert Boyer (2000), I note that periods of stability involve complementary institutional hierarchies and, in more pluralistic or democratic regimes, institutionalized compromise; and that, in periods of instability, one structural form tends to disrupt these institutional hierarchies and leads to essentially political struggles to roll back past compromises and establish new ones. This was particularly evident during the 'Asian crisis', when the operation of money and credit systems began to dissolve the institutional complementarities of the LWNS, prompting neoliberal policy adjustments and/or new forms of control over capital flows to preserve the overall developmental logic in new circumstances.

Each LWNS had its own distinctive economic regime and mode of regulation that combined its four features with other functions, scales of action, and modes of governance. This means there was no pure crisis in and/or of the LWNS - let alone one with identical outcomes. In some cases, one finds greater continuity, linked to the view that there was a crisis in the prevailing form of the LWNS, which required only incremental shifts to move towards a new regime (e.g., Singapore, Taiwan); in others, there was more discontinuity - especially in declared policy changes rather than actual outcomes - linked to a discursively-constructed domestic crisis of the DS, to the constraints linked to accession to the World Trade Organization (WTO), and, post-crisis, to structural conditionalities and externally reinforced imposition of domestically promoted radical restructuring (e.g., Korea). Even in Korea, Thailand, and Indonesia, where the crisis was greater, there were significant continuities. Malaysia pursued a different strategy, reinforcing the LWNS strategy, and the IMF later conceded that it had merits (cf. Iceland following the North Atlantic financial crisis). 
The export-oriented LWNS system had its own vulnerabilities and crisis-tendencies. First, as export-led growth continued, it became harder to maintain the relative 'structured coherence' of the EANICs' modes of growth and régulation. The neoliberal promotion of global flows of disembedded capital and domestic de-regulation had a particularly adverse impact on the virtuous Kaldorian relation between exportism and growth in the LWNS paradigm. Internal pressures also developed to adopt more Schumpeterian (innovation and competitiveness-oriented) forms of economic intervention and workfare - either through gradual adaptation of the DS in alliance with producer interests, local authorities, and the wider scientific and R\&D community or through its more radical neo-liberal rollback. Second, rising personal incomes and popular demands for social welfare weakened the effectiveness and acceptability of the initial workfare regime. Third, the coherence of the economic core and the primarily national matrix of regulation that had permitted concerted state guidance were both challenged by growing interest in promoting inward and outward direct investment as well as a regional division of labour that stretches production networks across national border. Fourth, there were growing external pressures to 'rollback' the DS through such measures as privatization, liberalization, deregulation, market proxies, reduced taxes, and an opening to foreign direct investment. This arose in different ways - through preparing to meet the free trade requirements of entry into the WTO, through the impact of the Asian crisis, or simply through massive trade dependence on US markets that made export-oriented economies vulnerable to American pressure to adopt neo-liberal measures favourable to US interests.

Responding adequately to these four sets of pressures would have required major institutional changes in the economy and state that would inevitably threaten certain sectors of the dominant economic and political elites and thereby destabilize the hegemonic constellation and its power bloc within and beyond the state. Not all states had the institutional capacities and balance of forces to resolve the resulting economic and political institutional crises - Japan is the most notorious example of state failure here, despite continuing export competitiveness in many industries (with Abenomics the latest example of economic policy failure). Among first-generation EANICs, Korea was affected in the early to mid-1990s by the rise of strong neoliberal currents among the chaebols and US-trained economic mandarins and by 
attempts to rollback key elements in the inherited LWNS model. Nonetheless, as we shall see below, it has re-invented rather than rejected the DS paradigm. Second-tier East Asian NICs were hard-hit by the economic crisis because of their much faster catch-up process, more rapid integration into the emerging regional as well as global division of labour, greater economic, social, and political stresses due to uneven development, and greater vulnerability to large and sudden inflows (and outflows) of short-term, speculative capital. They also had less effective state capacities.

'Globalization' did not affect all East Asian economies in the same way. But we can note two general sets of factors that were mediated through the private more than the public sector. First, there were growing cost pressures as they competed with each other and even newer NICs in the region (such as China and Vietnam) for market share, sought to cover the costs of new rounds of investment and technological innovation, tried to cope with a rising real effective exchange rate both against the dollar, to which national monies were pegged, and, more seriously, against the yen (which was then depreciating against the dollar), and addressed workers' demands for higher wages and social welfare benefits. Second, there was the de-stabilization of national systems of credit allocation through the attempted global imposition of liberalization and deregulation, the use of short-term dollardenominated foreign credits to finance long-term investment, the additional inflow of short-term speculative 'hot money' and resulting excess liquidity, and the search for easier profits in land, property, stock market speculation and intensified political corruption as compared to industrial production. In general, the free movement of global capital made the East Asian economies (especially second-tier NICs) increasingly vulnerable to currency speculation even though many still had strong underlying 'fundamentals', namely, high domestic savings, budget surpluses, low inflation, and good growth prospects. Unsurprisingly, then, the crisis itself was triggered by the collapse of financial bubbles generated by hypermobile speculative capital (aided and abetted by some local economic and political forces) rather than by long-term balance of trade problems. The most vulnerable EANICs in this regard were those that had embarked on liberalization and hence weakened their LWNS neo-mercantilist defences. 
Hong Kong, Singapore, and Taiwan had the strongest trading accounts and foreign exchange reserves and were less affected than South Korea, which had severe short-term debt problems and a deeper institutional crisis. Singapore and Taiwan were also protected by strong prudential controls over the allocation of credit; and Hong Kong benefited from background financial and political support from the People's Republic of China, which had no interest in a spectacular collapse of the Hong Kong economy so soon after its 'return to the motherland'. Second-tier NICs (notably Thailand, Indonesia, Malaysia, and the Philippines) suffered even more from acute pressures of foreign debt and domestic institutional crises. The 'IMF-3' (South Korea, Thailand, and Indonesia) were initially drawn furthest into the 'illogic' of globalization due to the IMF and World Bank's 'neo-liberal' conditionalities and structural adjustment programmes. But, after the initial shock, South Korea reoriented its neo-statist strategy around the knowledge-based economy and financialization. More generally, there was growing interest in regional initiatives, beginning with the deepening of the intra-regional division of labour and associated intra-regional trade and, perhaps, despite initial IMF and US opposition, towards a relatively 'dollar-free' regional currency regime.

\section{Recalibrating Developmental States versus Post-Developmental States}

The problem of reinvigorating and reregularizing accumulation after the Asian crisis involved more than finding new ways to manage the same dominant structural forms. For the relevant spatio-temporal dynamics and contexts had changed, the inherited forms of the DS were in crisis, the horizons for catch-up competitiveness had altered, new accumulation strategies and state projects were emerging, and, in this context, the most important structural forms and their contradictions and dilemmas also changed. Moreover, far from being purely regional, the crises of exportism and the LWNS were closely linked to the exhaustion of the Atlantic Fordist growth dynamic to which EANIC exportism had been closely tied. This indicated the need to develop a new catch-up competitiveness strategy as well as to rebalance export-led growth and domestic demand. The two main strategies considered in this regard have been the $\mathrm{KBE}$ and financialization and each has been pursued at multiple scales from the local through to the supra- and trans-national, taking advantage of new opportunities 
opened by regional integration and the rise of China as the new regional and global economic powerhouse.

In terms of catch-up strategies, the dominant competitive forces are those that set the terms of competition in the most important market. These include not only various kinds of firm-specific assets and competences but also meso- and macroeconomic factors and forces. This has been captured in the idea of 'structural competitiveness'. The OECD sees this as

a way of expressing the fact that, while the competitiveness of firms will obviously reflect successful management practice by entrepreneurs or corporate executives, it will also stem from the strength and efficiency of a national economy's productive structure, its technical infrastructure, and other factors determining the 'externalities' on which firms build, i.e., the economic, social, and institutional frameworks and phenomena which can substantially stimulate or hamper both the productive and competitive thrust of domestic firms (Chesnais 1986: 86-87).

Once deemed relevant, meso- and macro-economic competitiveness can be targeted for action. This extends economic competition to diverse extra-economic institutional factors and socio-cultural conditions that bear on economic performance and it thereby subjects entire societal regimes to the audit of the world market. Which extra-economic factors matter depends on the competitive positioning (comparative and competitive advantages) of firms and sectors in the changing international division of labour and hence the position of local, regional, and national economies in the hierarchically ordered world system. At any given time growth in a given economy will reflect patterns of decline (due to competitive disadvantage), growth (due to competitive advantage), and recovery (thanks to effective restructuring of uncompetitive sectors). This invites the question whether DS are being reinvented or replaced by 'post-developmental states'. A clue is found in Ó Riain's distinction between bureaucratic and network developmental states. For, although he does not note it, the DBS is more suited to catch-up strategies in heavy industries and the DNS to catching-up in the software industries that Ó Riain studied in Ireland, Israel, and Taiwan. This distinction can be elaborated by referring to 
Herbert Kitschelt's study of the complex interactions among national institutions, governance structures, and industrial sectors in different stages of economic development. The next two paragraphs summarize his arguments.

Based on general theoretical observations and close attention to the historical trajectories of Japan, Europe, and the USA, Kitschelt suggested that different technologies and industrial sectors are best promoted through different governance mechanisms (Kitschelt 1991; cf. Freeman 2002; Perez 2002). Industrialization in the late $18^{\text {th }}$ century was based on light consumer and investment goods, notably textiles and machine tools, which involved loosely coupled technological systems with linear interactions. These can be developed in decentralized, market-oriented economies with a weak state. The next wave of industrialization, in the mid- $19^{\text {th }}$ century, relied on steam power, iron, coal, and railway construction, all of which enabled economies of scale. This favoured oligopolistic markets and industrial centralization through large corporations and, where these were weak or absent, required a stronger state role in industrial development. On this basis, latecomers, such as Germany, Japan and a then neo-mercantilist USA could catch up and, indeed, overtake England in these industrial sectors. In turn, new science-based technologies that were developed at the end of the $19^{\text {th }}$ century were compatible with two kinds of governance. The first is networks of medium-sized enterprises with close linkages between customers and suppliers and close interaction with a not-for-profit research infrastructure of universities and laboratories; the second involves large corporations that organized mass production industries based on economies of scale. Using Ó Rian's terminology, one might infer that the flexible specialization sectors are more suited to a developmental network state and mass production sectors to its bureaucratic variant.

The next round of major technological innovations comprised, according to Kitschelt, tightly coupled, complex systems with high development costs and uncertain outcomes (e.g., nuclear fission, aircraft, large computer and telecoms systems, advanced chemical processing, pharmaceuticals) where public agencies had a key role (cf. on the USA, Weiss 2014) and where any catch-up would require strong support from developmental states with deep pockets (e.g., Japan, China). Finally, Kitschelt identifies some fifth generation technologies with loose coupling, modest 
capital requirements and modest economies of scale, and serious causal complexity and uncertainty. Examples include computer software, customized microprocessors, genetically engineered products and drugs, and specialty chemicals. These technologies are suited to mixed private and public networks that interact flexibly in the fields of R\&D, manufacturing, and service provision to link producers and consumers. Kitschelt concluded that strongly statist economies (such as France) and strongly liberal economies with weak non-profit research infrastructures (such as the UK) will lose out in these sectors but that the USA, Japan, and Germany could remain competitive in at least some of them (Kitschelt 1991: 471-5; cf., on the USA, Weiss 2014). Although he did not study the EANICs, his taxonomy does have obvious implications for their past evolution and future trajectories as developmental states.

Without endorsing all aspects of Kitschelt's analysis, which is consistent with much of the more detailed case study literature, it does highlight the moving horizon of catch-up competitiveness and the different kinds of institutional and governance arrangements appropriate to different horizons of catch-up competitiveness. It also indicates that the one-sided stress in some DS literature on the state's role in economic planning is misleading about the governance mix that facilitated catch-up and even leapfrogging. For, although the state may have had crucial roles in the 'government + governance' mix that facilitated development, it was typically one powerful player within a more complex set of arrangements that involved publicprivate partnerships, networks, clubs, and other forms of cooperation, sometimes with cross-border alliances and other arrangements. This suggests in turn that these states may have had capacities and resources to recalibrate their catch-up strategies as the frontiers of competition and competitive hierarchies changed. In this sense, then, less reliance on bureaucratic state controls may not signal the end of the DS but a reasonable adaptation of structures and strategies in response to changes in the technological, organizational, and financial reference points for catch-up competitiveness.

The knowledge-based economy 
Following the search for a plausible new economic imaginary after the crisis in/of Atlantic Fordism and its global repercussions, the knowledge-based economy (KBE) emerged as the hegemonic post-Fordist imaginary and was translated into various economic strategies at firm and sectoral level and economic policies at local, regional, and national state level. It was promoted by leading corporations, states at different levels, and international bodies, including the Asia-Pacific Economic Cooperation and ASEAN as well as more global organizations such as the OECD, World Bank, and WTO. The KBE applies knowledge reflexively to knowledge production to develop technology, process, and products and this gives knowledge and knowledge work a major role in shaping the relations of production (Castells 1996; Jessop 2002; Sum and Jessop 2013). Most sectors become more knowledgeintensive, reflecting a more general shift from investment- to innovation-driven competitiveness, cf. Porter 1990). In the EANICs, this reorientation was also a specific response to crises in their patterns of export-led growth and involved restructuring 'developmental states' rather than actively rolling them back entirely or allowing them to wither away. What was required was more effort to promote the network economy, network forms of governance, and a network society (Castells 1996). If so, whereas the developmental network state is pre-adapted to promoting the KBE strategy, the developmental bureaucratic state would need to recalibrate and reorient its inherited LWNS forms of economic and social governance further towards partnership and networking arrangements to strengthen existing $\mathrm{KBE}$ elements in their respective economic spaces and to develop, where possible, newer technologies. Such changes have been strongly promoted by international bodies such as the OECD, APEC, and ASEAN and international consultancies as well as, domestically, by some government agencies, industry associations, strategic bodies, think tanks, and so on.

Using the same schema as that deployed to analyse catch-up competitiveness in the LWNS, the two dominant structural forms in the ideal-typical KBE are capital and competition. The primary aspect of capital is the valorization of knowledge as a fictitious commodity such that the production, management, distribution, and use of knowledge becomes a key driver of economic growth, wealth generation, and job creation across the private, public, and 'third' sectors. This is related to a shift in the relative importance of different kinds of competition. Specifically, there is a shift from 
investment-led Kaldorian, catch-up competitiveness to innovation-led Schumpeterian catch-up competitiveness. In developmental states, this is associated with moderate intellectual property regimes to facilitate rather than block knowledge sharing so that as many firms as possible benefit from new opportunities created by R\&D activities and other forms of innovation. This is reflected in measures to: (1) to create and valorize design- and knowledge-intensive capital and manage the tensions between intellectual commons and intellectual property; (2) to facilitate technological intelligence gathering, create independent technological capacities and promotes innovative capacities, technical competence, and technology transfer; (3) make the wage relation more flexible, use the social wage relation and social policy to provide flexicurity, reskill and upgrade the workforce (including through the global war for talents), and promote the supply of enterprise skills and competencies; (4) relax national monetary controls to facilitate the internationalization of capital movements (while, in the EANICs, preserving prudential controls over hot money flows). In turn, 'Third Way' social policies would address new forms of social exclusion, especially for those excluded permanently or temporarily from the asset-based welfare economy that is common to the EANICs.

The Asian crisis prompted a revaluation of the LWNS strategy based on investment-led competitiveness and prompted a turn to investment- and innovation-led KBE strategies. This was not a radical rupture in Japan or the first-generation EANICs because they had already embraced the information economy and society, promoted national systems of innovation, and strengthened the learning economy. Thus we find a wideranging set of discursive, institutional, and policy changes in government and governance. Symptomatic of this reorientation are Korea's strategy to become a KBE, endorsed by the OECD and World Bank (Chu 2009); Taiwan's commitment under the Democratic Progressive Party to become a 'Green Silicon Island' based on the KBE, sustainable development, and social justice as well as its promotion of an 'e-Taiwan' project to build e-business, e-government, and an e-society (in general, Chen and Lee 2004); Singapore's strategy to become an 'Intelligent Island'; Malaysia's '2020 vision' and master planning to move from a production-based economy to a 'K-economy'; and, albeit more rhetorically, Hong Kong's strategy in the 1990s (recommended by scholars and consultants linked to Massachusetts Institute of Technology) to become a KBE specializing in knowledge-intensive business 
services for the Pearl River Delta (on this, Masayama and Vandenbrink 2003; and Sum and Jessop 2013).

To illustrate the potential continuity between the developmental state and the $\mathrm{KBE}$, let us note that, under President Lee Myung-bak, South Korea formed a Ministry of Knowledge Economy (MKE) in 2008. Its mission was to promote the knowledge economy, which would add value to traditional goods and services through greater levels of research and innovation intelligence, adding value and making them more competitive globally. It declared that, 'different from other economic models which rely primarily on natural resources or manpower, knowledge will be the primary engine of productivity and growth for the Korean economy' (italics in original). Above all, 'the Ministry strives to assemble traditional industrial know-how, cutting edge $R \& D$, and strong pro-business policies' (Ministry of Knowledge Economy 2008). Its remit also included developing new growth engines by supporting Information and Communications Technologies (ICT) and high-end manufacturing, promoting foreign trade, attracting FDI, and develop environmentally-friendly economic projects by promoting a green economy (Erawatch 2012). This strategy was revived by another new ministry in 2013: the Ministry of Science, ICT and Future Planning (MSIP), which was tasked with leading the development, coordination and implementation of 'creative economy' policies.

The MISP initiative reflected the vision of incoming President Park Geun-hye. She wanted to create a 'Second Miracle on the Han River' by promoting a 'creative economy'. This would stimulate growth and employment through 'the convergence of science and technology with industry, the fusion of culture and industry, and the blossoming of creativity in the very borders that were once permeated by barriers' (Park 2013). Reflecting a Schumpeterian view of catch-up competitiveness, President Park's programme emphasized the key role of entrepreneurs as 'carriers of innovation' in products, services, processes, markets, and business models. Her programme incorporates six strategies to achieve these goals: establish an ecosystem that promotes the creation of startups; strengthen the role of start-up companies and SMEs and enhance their ability to enter global markets; generate new industries as growth engines; foster world-class creative talent; strengthen 
Korea's science, technology, and ICT to increase innovation capabilities; and promote a creative economic culture within Korean society (cf. Connell 2013).

\section{Financialization}

The other main strategy that emerged in the aftermath of the crisis of Atlantic Fordism in the 1980s was financialization. This reflects the liberal (or money) proto-concept of control and prioritizes the logic of flows in the world market over the interests of productive capital considered as a stock of fixed assets to be valorized in specific places and at particular times. In its extreme form, it privileges fast, hyper-mobile money but this is unsustainable as a general model on a global scale, especially as the long-term viability of financialization depends on the 'real economy' (which is always mediated through money and credit relations). Thus financialization as a general economic strategy for national territorial states (as opposed to offshore tax havens, citystates or microstates) is oriented to promoting global financial centres or regional financial hubs in particular places and/or to promoting the interests of financial (or interest-bearing) capital. Where neo-liberal regime shifts occurred (e.g., the USA, UK, Ireland), financialization has developed into a finance-dominated accumulation regime that subordinates other aspects of the economy to the interests of financial capital even after the spectacular eruption of financial crisis in these economies in 2007-8. In contrast, the EANICS underwent only neo-liberal policy adjustments within the prevailing institutional framework of their respective developmental states. Indeed, the path-dependent nature of their industrial profiles and the institutional bases of their export competitiveness precluded the kind of radical neoliberal regime shifts noted above. Thus their governments pursued a more hybrid strategy for financialization, which involved controlled de-regulation of financial markets and capital flows together with further measures to strengthen asset-based welfare regimes based on the private wage, household credit, and high savings for home ownership, equity investment, education, and pensions. Despite the shocks to asset-based welfare in the aftermath of the 'Asian crisis' and the contagion effects of the North Atlantic financial crisis, financialization has continued, aided by a more robust regulatory and institutional framework than is found in the USA, the UK, and Ireland. 
In addition, catch-up competitiveness has been extended to include financialization in several ways: promoting the interests of national or regional financial institutions and organizations, competing for regional financial hub status, and seeking to offer the best regulatory frameworks for financial institutions and services. These measures can coexist with the KBE strategy, especially where financialization is related discursively to knowledge-intensive business services, financial innovation (e.g., through new financial instruments), the role of venture capital or private equity capital, and capturing the value-added of high-end asset and wealth management services. This strategy can also backfire when it leads to speculative bubbles in stocks and shares, commodities, and real estate (including private housing in asset-based welfare regimes).

In Japan, the EANICs, and, more recently, China, this strategy cannot be achieved solely through private-sector initiatives. As Jokin Lai observed regarding Korea's strategy, it 'also required government cooperation in at least reforming and liberalising the sector through policy and legislative changes' (2012: 64). Before President Lee Myung-bak highlighted the KBE strategy in 2008 with the formation of the Ministry of Knowledge Economy, a strategy to make South Korea the Northeast Asia Financial Hub Road Map was launched in December 2003 by President Roh Moo-hyun. This was part of a broader programme to advance national development goals by building a globally competitive financial sector, now considered an essential part of, and stimulus to, a high value-added, knowledge-based service sector. As Yoon-shik Park, an international finance professor, notes, 'successful international financial centers also nurture the development of other advanced knowledge service industries such as world-class medical services and educational institutions, sophisticated telecommunications, and renowned cultural institutions' (2011: 4). Strategic measures included deregulating capital markets, liberalizing the capital account framework and foreign exchange system, and attracting foreign participation in financial markets. A second roadmap in 2005 reflected criticisms from the Seoul Financial Forum (an industry think tank) about the lack of ambition to date and reasserted the importance of the role of state strategic interventions:

An international financial center requires modern infrastructure in such areas as telecommunication and high-speed Internet connections, convenient air and sea transport, modern mass transit and other local transportation 
system, electricity, gas, sanitation and health systems, and first-class education facilities from kindergarten through graduate school. An efficient financial center also needs advanced legal and accounting firms, hotel and other lodging facilities, modern housing, and well-educated and Englishconversant finance professionals and support staff. Visas and work permits for foreign workers should be readily available as well (Park 2011: 8).

The question remains whether this reflects a shift in the developmental state as its catch-up competitiveness strategy changes or a move to a post-developmental state. I return to this question in the conclusions. A more critical observation is that, despite this commitment, Korea's financialization strategy has had limited success compared to continued advances in other areas of the knowledge-based economy and compared with rivals such as Singapore, Hong Kong, Shanghai and, indeed, Bahrein.

In contrast, Lee Kuan-Yew had already committed his government to developing Singapore as an international financial centre in 1968 and, in addition to time-zone advantages, an entrepôt and entrepreneurial tradition, and English and Chinese language skills, it benefitted from two major sovereign wealth funds, Temasek Holdings (1974-) and the Government of Singapore Investment Corporation (1981-). This financial hub strategy was reaffirmed after the Asian crisis to exploit opportunities from continued economic growth in North and Southeast Asia in order to rise up 'the knowledge-based value-chain' in financial services. The current strategy is to enable Singapore-based financial institutions to service foreign businesses investing in Greater China, finance Chinese enterprises and manage offshore Chinese wealth; and offer Indian businesses high quality legal, technology and financial infrastructure to assist their fund-raising and overseas expansion efforts. Further, Singapore-based institutions would intermediate economic recovery in Southeast Asia by financing or underwriting the risks of investing in companies and countries in the region (cf. Economic Review Committee 2002).

More recently still, China has been pursuing a gradual, stepwise internationalization of the Renminbi as an international currency that may eventually rival the US dollar and has established the Asian Infrastructure Investment Bank to challenge the World 
Bank and Asian Development Bank. In addition the State Council unveiled a ninepoint capital market reform plan to develop and internationalize its financial sector. Relevant measures include the creation of a China (Shanghai) Pilot Free Trade Zone in September 2013, linking the Shanghai and Hong Kong stock markets to permit cross-border investment, deregulating futures markets, and making it easier to float shares and issue local government bonds. Financialization is a crucial aspect of China's new economic strategy.

\section{Conclusions}

My chapter has critiqued the DS as a theoretical and policy paradigm and suggested an alternative approach that addresses the issues that prompted these paradigms. This alternative may enable a rapprochement between those who claim that neoliberalism has superseded the developmental state and those who argue that the latter remains essentially unaltered. I introduced an alternative state- and regulationtheoretical framework that is relevant not only to the co-existence of Atlantic Fordism and East Asian exportism but also to new or adapted strategies following the crisis of Fordism and exportism and the contagion effects of the North Atlantic Financial Crisis. These new strategies are the knowledge-based economy (or creative economy) and financialization, each of which involves, in different ways, dissolutionconservation effects in the developmental state, that is, discontinuities within a broader framework of continued commitment to catch-up competitiveness. It is interesting to note how strategies are framed in terms of more general economic imaginaries but adapted to local conditions through recontextualization and rearticulation with past structures and strategies. As the horizons of catch-up competitiveness change, so do the discursive, institutional, governance, and policy conditions needed for success. But, in the light of the preceding remarks, I suggest that we are witnessing shifts in the developmental state rather than a transition to a post-developmental state. The changes reflect shifts in the horizons of catch-up competitiveness, corresponding forms of governance, and new alliances, not the fundamental goal of catching up. In this case, the general principle that, plus ça change, plus c'ést la même chose, seems to hold. 


\section{Endnotes}

1. In the tradition of enlightened despotism, the right to rule a state carried with it the duty to develop it for the common good.

2. Andrew Hamilton, the first US Secretary of the Treasury, developed a plan to industrialize the United States that deployed the same theoretical arguments current in Continental Europe. He advocated bounties and incentives to manufacturers to be financed from the tariffs imposed on imported manufactured goods (Hamilton 1791).

3. Two other sources of demand are public sector investment in a closed economy (e.g., rearmament) and demand from the agricultural sector (Kaldor 1971).

4. More detailed historical analyses would also need to consider the role of land reform at the cost of large landowners, especially in South Korea and Taiwan.

5. This section draws on Jessop $(2005,2015)$

\section{References}

Bayar, A.H. (1996) 'The developmental state and economic policy in Turkey', Third World Quarterly, 17 (4), 773-85.

Boyer, R. (2000) 'The political in the era of globalization and finance', International Journal of Urban and Regional Research, 24 (3), 274-322.

Boyer, R. (2013) 'The Chinese growth regime and the world economy', in R. Boyer, H. Uemura, and A. Isogai (eds), Diversity and Transformations of Asian Capitalisms, London: Routledge, 184-205.

Boyer, R. and Saillard, Y. (eds) (2001) Régulation Theory: the State of the Art, London: Routledge.

Breslin, S. (2011) 'The "China model" and the global crisis: from Friedrich List to a Chinese mode of governance', International Organization', 87 (6), 1323-43.

Caldentev, E.P. (2008) 'The concept and evolution of the developmental state', International Journal of Political Economy, 37 (3), 27-53.

Campbell, J.L., and O.K. Pedersen, O.K. (2007) 'Institutional competitiveness in the global economy', Regulation and Governance, 1 (3), 230-46.

Cerny, P.G. (1990) The Changing Architecture of Politics, London: Sage. 
Chang, H.-J. (2005) Kicking Away the Ladder: Development Strategy in Historical Perspective, London: Anthem.

Chen, T-Y. and Lee, J.S. (eds) (2004) The New Knowledge-Economy of Taiwan, Cheltenham, UK: Edward Elgar.

Chesnais, F. (1986) 'Science, technology and competitiveness', STI Review, 1, 86129.

Chu, Y.-W. (2009) 'Eclipse or reconfigured? South Korea's developmental state and challenges of the global knowledge economy', Economy and Society, 38 (2), 278-303.

Connell, S. (2013) Building a Creative Economy in South Korea: Analyzing the Plans and Possibilities for New Economic Growth, Washington DC: Korea Economic Institute of America, Academic Papers, 10 December.

Cumings, B. (1999) 'The Asian crisis, democracy and the end of late development', in T.J. Pempel (ed.), Politics of the Asian Economic Crisis, Ithaca: Cornell University Press, 237-76.

Economic Review Committee, Sub-Committee on Services Industries: Financial Services Working Group (2002) Positioning Singapore as a Pre-eminent Financial Centre in Asia, Singapore.

Erawatch (2012) 'Organisation: Ministry of Knowledge Economy', Brussels: European Commission.

Evans, P.B (1995) Embedded Autonomy: States and Industrial Transformation, Princeton: Princeton University Press.

Freeman, C. (2002) 'Continental, national and sub-national innovation systems complementarity and economic growth', Research Policy, 31 (2), 191-211.

Freeman, C. (2004) 'Technological infrastructure and international competitiveness', Industrial and Corporate Change, 13 (3), 541-69.

Gerschenkron, A. (1962) Economic Backwardness in Historical Perspective, Cambridge: Cambridge University Press.

Grou, P. (1985) The Financial Structure of Multinational Capitalism, Leamington Spa: Berg.

Hamilton, A. (1791) Report on the Subject of Manufactures. Reprinted in F. Taussig (ed.), State Papers and Speeches on the Tariff, Cambridge, MA: Harvard University Press.

Jessop, B. (2002) The Future of the Capitalist State, Cambridge: Polity. 
Jessop, B. (2005) 'Beyond developmental states: a regulationist and state-theoretical analysis', in R. Boyd and T.-W. Ngo (eds), Asian States: Beyond the Developmental Perspective, London: Routledge, 19-42.

Jessop, B. (2015) 'Comparative capitalisms and/or variegated capitalism', in I. Bruff, M. Ebenau, and C. May (eds), New Directions in Critical Comparative Capitalisms Research, Basingstoke: Palgrave-Macmillan, 65-82.

Jessop, B. and Sum, N.-L. (2006) Beyond the Regulation Approach: Putting Capitalist Economies in its Place, Cheltenham: Edward Elgar.

Johnson, C. (1982) MITI and the Japanese Miracle: The Growth of Industrial Policy, 1925-1975, Stanford, CA: Stanford University Press

Johnson, C (1999) 'The developmental state: odyssey of a concept', in M. WooCumings (ed.), The Developmental State, Ithaca, NY: Cornell University Press, 32-60.

Kaldor, N. (1971) 'Conflicts in national economic objectives', Economic Journal 81 (1), 1-16.

Kitschelt, H. (1991) 'Industrial governance structures, innovation strategies, and the case of Japan: sectoral or cross-national comparative analysis?', International Organization 45 (4), 453-93.

Lai, J. (2012) Financial Crisis and Institutional Change in East Asia, Basingstoke: Palgrave-Macmillan.

List, F. (1827) Outline of American Political Economy. In The Life of Friedrich List and Selection from his Writings, ed. M.E. Hirst. London: Smith, Elder \& Co. $<1909>$.

List, F. (1837) The Natural System of Political Economy, London: Cass <1983>.

Masayama, S. and Vandenbrink, D. (eds) (2003) Towards a Knowledge-Based Economy: East Asia's Changing Industrial Governance, Singapore: Institute for East Asian Studies.

Ó Riain, S. (2000) 'States and markets in an era of globalization', Annual Review of Sociology, 26, 187-213.

Ó Riain, S. (2004) The Politics of High-Tech Growth. Developmental Network States in the Global Economy. Cambridge: Cambridge University Press.

Overbeek, H. (1990) Global Capitalism and National Decline: The Thatcher Decade in Perspective, London: Unwin Hyman. 
Park, Y.S. (2011) 'Developing an International Financial Center to Modernize the Korean Service Sector', Washington DC: Korea Economic Institute of America Academic Papers, \#47.

Park, G.H. (2013) 'Opening a New Era of Hope (18th Presidential Inaugural Address)', 25 February, Office of the President (Republic of Korea).

Perez, C. (2002) Technological Revolutions and Financial Capital: The Dynamics of Bubbles and Golden Ages, Cheltenham: Edward Elgar.

Perrotta, C. (1993) 'Early Spanish mercantilism: the first analysis of underdevelopment', in L. Magnusson (ed.), Mercantilist Economics, Boston: Kluwer, 17-58.

Porter, M.E. (1990) The Competitive Advantage of Nations, London: Macmillan.

Reinert, E.S. (1995) 'Competitiveness and its predecessors - a 500 year crossnational Perspective', Structural Change and Economic Dynamics, 6: 23-42.

Reinert, E.S. (1999) 'The role of the state in economic growth', Journal of Economic Studies, 26 (4/5).

Reinert, E.S. (2004) 'How rich nations got rich. Essays in the history of economic policy', Working Paper Nr. 2004/01, University of Oslo: SUM.

Reinert, E.S. (2010) Developmentalism. Working papers in Technology, Governance, and Economic Development, no. 34, Oslo: The Other Canon Foundation and Tallin: Tallin University of Techology.

Schmoller, G. (1897/1976) The Mercantile System and its Historical Significance, New York: Macmillan, Kelley.

Schumpeter, J.A. (1934) Theory of Economic Development: An Inquiry into Profits, Capital, Credit, Interest and the Business Cycle, Boston, MA: Harvard University Press <1962>

Sum, N-L. (1994) Reflections on Accumulation, Regulation, the State, and Societalization: a Stylized Model of East Asian Capitalism and an Integral Economic Analysis of Hong Kong, PhD dissertation, University of Lancaster.

Sum, N-L. and Jessop, B. (2013) Towards Cultural Political Economy: Putting Culture in its Place in Political Economy, Cheltenham: Edward Elgar.

Tribe, K. (1995) Strategies of Economic Order: German Economic Discourse 17501950, Cambridge: Cambridge University Press.

Tribe, K. (2008) 'List, Friedrich (1789-1846)', in S.N. Durlauf and L.E. Blume (eds) The New Palgrave Dictionary of Economics, $2^{\text {nd }}$ edn, Palgrave Macmillan. 
van der Pijl, K. (1984) The Making of the Atlantic Ruling Class, London: Verso.

van der Pijl, K. (1998) Transnational Classes and International Relations, London: Routledge.

Weber, M. (2009) General Economic History, New Brunswick, NJ: Transaction Books.

Weiss, L. (1998) The Myth of the Powerless State: Governing the Economy in a Global Era, Cambridge: Polity.

Weiss, L. (2014) America Inc.? Innovation and Enterprise in the National Security State. Ithaca, NY: Cornell University Press. 